\title{
Sosialisasi Energi Baru Terbarukan Untuk Pelajar SMP Annida Al Islamy Duri Kosambi, Cengkareng
}

\author{
Retno Aita Diantari ${ }^{1}$; Tasdik Darmana ${ }^{2}$ : Erlina ${ }^{3}$; Syarif Hidayat ${ }^{4}$; Jumiati $^{5}$; \\ Soetjipto Soewono $^{6}$; I Made Indradjaja ${ }^{7}$ \\ 1, 2, 3, 4, 5, 6, 7 Program Studi Teknik Elektro, Fakultas Teknik, Sekolah Tinggi Teknik PLN \\ ${ }^{1}$ retno.aita@sttpln.ac.id
}

\begin{abstract}
ABSTRAK
Energi listrik merupakan kebutuhan dasar manusia, yang terus meningkat sejalan dengan tingkat kehidupannya. Bahan bakar minyak/energi fosil merupakan salah satu sumber energi yang bersifat tak terbarukan (nonrenewable energy sources) yang selama ini merupakan andalan untuk memenuhi kebutuhan energi di seluruh sektor kegiatan. Kurangnya pemahaman siswa mengenai proses terjadinya energi listrik membuat mereka belum banyak melakukan penghematan energi listrik dalam kehidupan sehari-hari. Selama ini, sebagaian besar siswa dalam menggunakan energi listrik tidak memikirkan dampaknya terhadap kelestarian lingkungan hidup. Oleh karena itu, kegiatan sosialisasi energi baru dan terbarukan adalah salah satu upaya atau langkah yang dilakukan untuk mengetahui proses terjadinya energi listrik dan dampak dari energi fosil sehingga dapat menjaga kelestarian lingkungan. Kegiatan ini merupakan kegiatan sosialisasi yang dimotori oleh para dosen STT-PLN untuk memberikan edukasi kepada masyarakat tentang pentingnya memahami penggunaan energi listrik secara bijak dalam upaya menjaga lingkungan.
\end{abstract}

Kata kunci: Sosialisasi, Energi, Energi Baru Terbarukan

\begin{abstract}
Electrical energy is a basic human need, which continues to increase with the level of life. Oil fuel / fossil energy is one of the nonrenewable energy sources which the most important think to fulfill energy needs in all sectors of activity. The lack of students' understanding of the process of the occurrence of electrical energy makes them not much to save electricity in everyday life. During this time, most students in using electrical energy do not think about the impact on environmental sustainability. Therefore, the promotion of new and renewable energy is one of the efforts or steps taken to determine the process of the occurrence of electrical energy and the impact of fossil energy so that it can preserve the environment. This activity is a socialization activity led by STT-PLN lecturers to provide education to the public about the importance of understanding the use of electrical energy wisely in an effort to protect the environment.
\end{abstract}

Keywords: Socialization, Energy, Renewable Energy 


\section{PENDAHULUAN}

Energi merupakan komoditi strategis bagi suatu bangsa. Indonesia memiliki berbagai jenis sumber energi seperti energi fosil yang meliputi minyak bumi, gas bumi, dan batubara serta energi terbarukan yang terdiri atas matahari, angin, tenaga air, panas bumi dan biomassa. Sebagian besar sumber energi tersebut ditransformasi menjadi tenaga listrik. Listrik merupakan kebutuhan dasar manusia.

Listrik merupakan jendela peradaban menuju kemajuan suatu bangsa. Dengan adanya listrik maka kegiatan belajar mengajar, komunikasi, transportasi dan pelayanan kesehatan serta proses pembangunan dapat berjalan lancar. Karena itu, Pemerintah wajib menyediakan listrik dengan jumlah dan kualitas yang memadai bagi rakyatnya.

Sayangnya saat ini penggunaan energi listrik di Indonesia masih tergolong boros, sehinggaa konservasi energi menjadi hal yang harus dilakukan sejak dini.

Sumber energi baru terbarukan adalah sumber energi ramah lingkungan yang tidak mencemari lingkungan dan tidak memberikan kontribusi terhadap perubahan iklim dan pemanasan global, karena energi yang didapatkan berasal dari proses alam yang berkelanjutan, seperti sinar matahari, angin, air, biofuel, dan geothermal. Ini menegaskan bahwa sumber energi telah tersedia, tidak merugikan lingkungan, dan menjadi alasan utama mengapa EBT sangat terkait dengan masalah lingkungan dan ekologi. Persoalan energi merupakan kepentingan semua negara di dunia. Energi bukanlah merupakan komoditas biasa, akan tetapi merupakan komoditas strategis mengingat seluruh sistem dan dinamika kehidupan manusia dan negara tergantung kepada energi sebagai urat nadi kehidupan pada semua sektor. Program pemerintah dalam rangka mewujudkan kemandirian energi nasional bukanlah hal yang mustahil untuk dicapai. Keseriusan pemerintah yakni bagaimana terus meningkatkan pasokan energi dengan memaksimalkan berbagai potensi yang dimiliki dan belum tergarap maksimal. Pengembangan pemanfaatan EBT merupakan upaya yang harus didukung penuh oleh seluruh lapisan masyarakat. Ketergantungan akan energi fosil yang semakin menipis cadangannya akan membuat Indonesia terjerembab dalam krisis energi. Sejatinya, antisipasi terhadap krisis energi bisa diatasi yaitu dengan terus melakukan pemanfaatan terhadap EBT [1].

Potensi Energi Baru Terbarukan di Indonesia: Indonesia mempunyai potensi energi panas bumi yang bisa dijadian pembangkit sebanyak 28.910 MW dengan potensi terbesar di Sumatera $(12,837 \mathrm{MW})$ dan terkecil Papua (75 MW). Potensi limbah biomassa menjadi listrik sangat besar terutama dari limbah sawit (12.654 MW). Untuk produksi bahan bakar nabati (BBN), sampai dengan 2013 mampu memproduksi 2.805 kilo liter per tahunnya (diekspor $1.757 \mathrm{~kL}$ dan keperluan domestik $1.048 \mathrm{~kL})$. Untuk EBT [2]:

1. Energi air. Potensi pemanfaatan energi air di Indonesia sebesar 75.000 MW dengan pemanfaatan baru sekitar 9,4\% (8.671 MW, pembangunan pembangkit mikro-hidro pada tahun 2013 mampu menghasilkan energi sebesar $1.458 \mathrm{~kW}$ yang mengaliri $2.089 \mathrm{~K}$;

2. Energi Gelombang Laut. Indonesia sebagai negara kepulauan mempunyai potensi teoritis energi gelombang laut sebesar 141.472 MW dengan potensi teknis sebesar 7.985MW namun potensi praktisnya sebesar 1.995,2 MW;

3. Energi Panas Laut. Potensi nominal 10.809 MW, potensi teoritis 4.147 MW, potensi teknis $136.169 \mathrm{~kW}$, dan potensi praktisnya $41.012 \mathrm{~kW}$;

4. Energi Angin. Berpotensi menyediakan daya sebesar 61.972 MW;

5. Energi Surya. Sebagai negara tropis dengan matahari yang bersinar sepanjang tahun, Indonesia baru memanfaatkan PLTS berkapasitas 5.270 MW yang mengaliri 17.246 KK. 
Hasil kajian yang dilakukan Kementerian ESDM menunjukkan bahwa dengan konservasi energi, maka potensi penghematan bisa mencapai 35 persen. Untuk itu, sosialisasi kepada anak-anak usia sekolah merupakan salah satu upaya untuk menanamkan paradigma hemat energi sejak dini kepada anak-anak, sekaligus untuk membangun generasi baru yang hemat energi.

Saat ini energi yang dinikmati oleh masyarakat di Indonesia, khususnya listrik berbahan baku batu bara, minyak bumi, dan gas bumi. Bahan baku tersebut merupakan sumber energi fosil yang tidak terbarukan. Energi listrik yang kita nikmati berupa cahaya lampu, mobil atau motor yang dipakai untuk bepergian, sumbernya kebanyakan dari batu bara, minyak bumi, dan gas bumi. Itu semua barang yang tidak terbarukan dan suatu saat habis.

Untuk mendukung upaya dan program pengebangan EBT, pemerintah sudah menerbitkan serangkaian kebijakan dan regulasi yang mencakup Peraturan Presiden No. 5/2006 tentang Kebijakan Energi Nasional, Undang-Undang No. 30/2007 tentang Energi, Undang-undang No.15/1985 tentang Ketenagalistrikan, PP No. 10/1989 sebagaimana yang telah diubah dengan PPNo. 03/2005 Tentang Perubahan Peraturan Pemerintah No. 10 Tahun 1989 tentang Penyediaan dan Pemanfaatan Tenaga Listrik dan PP No. 26/2006 tentang Penyediaan \& Pemanfaatan Tenaga Listrik, Permen ESDM No. 002/2006 tentang Pengusahaan Pembangkit Listrik Tenaga Energi Terbarukan Skala Menengah, dan Kepmen ESDMNo.1122K/30/MEM/2002 tentang Pembangkit Skala Kecil tersebar. Saat ini sedang disusun RPP Energi Baru Terbarukan yang berisi pengaturan kewajiban penyediaan dan pemanfaatan energi baru dan energi terbarukan dan pemberian kemudahan serta insentif [3].

Kegiatan sosialisasi energi baru dan terbarukan adalah merupakan upaya atau langkah yang dilakukan untuk mengurangi ketergantungan terhadap energi fosil dan sekaligus menjaga kelestarian lingkungan. Kegiatan ini merupakan kegiatan sosialisasi yang dimotori oleh para dosen STT-PLN untuk memberikan edukasi kepada masyarakat tentang pentingnya memahami penggunaan energi listrik secara bijak dalam upaya menjaga lingkungan.

\section{METODE}

Metode pelaksanaan yang digunakan dalam pelaksanaan P2M ini adalah :

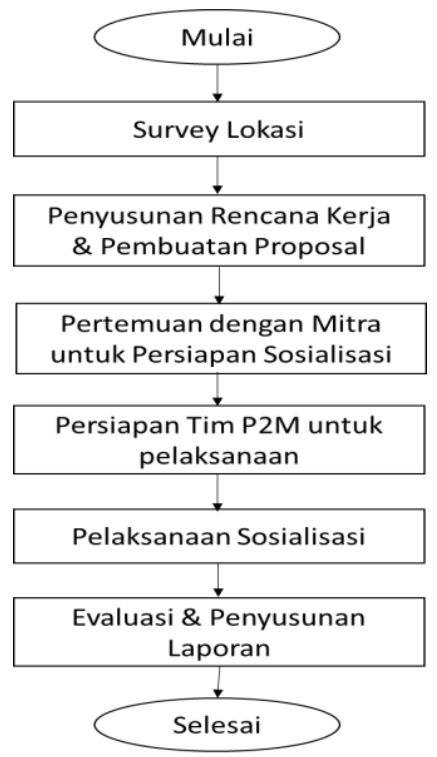

Gambar 1. Diagram Alir P2M 
Tabel 1. Metode Pelaksanaan P2M

\begin{tabular}{|c|l|c|}
\hline No. & \multicolumn{1}{|c|}{ Kegiatan } & Waktu \\
\hline 1 & Survey kebutuhan mitra & 29 Agustus 2018 \\
\hline 2 & $\begin{array}{l}\text { Melakukan diskusi dengan tim P2M untuk menganalisa kebutuhan } \\
\text { dan permasalahan yang di hadapi mitra }\end{array}$ & 5 September 2018 \\
\hline 3 & $\begin{array}{l}\text { Survey kedua membicarakan mengenai format pelaksanaan P2M } \\
\text { yang telah dirancang P2M kepada mitra. }\end{array}$ & 7 September 2018 \\
\hline 4 & Mengusulkan proposal P2M kepada LP3M STT-PLN & 11 September 2018 \\
\hline 5 & Proposal tim disetujui oleh LPPM STT-PLN & 11 Oktober 2018 \\
\hline 6 & $\begin{array}{l}\text { Melakukan rapat koordinasi untuk melakukan persiapan dan } \\
\text { pembagian tugas dalam pelaksanaan P2M }\end{array}$ & 5ovember 2018 \\
\hline 7 & Membuat kesepakatan dengan mitra untuk pelaksanaan P2M & 13 November 2018 \\
\hline 8 & Pelaksanaan P2M & 22 November 2018 \\
\hline
\end{tabular}

Sifat kegiatan ini adalah melakukan penyuluhan dan sosialisasi tentang energi baru terbarukan untuk pelajar SMP ANNIDA AL ISLAMY dan kaitannya dengan lingkungan hidup.

Setiap siswa diberikan penjelasan beberapa jenis pembangkit listrik yang ramah lingkungan dan tidak menimbulkan pencemaran udara, seperti pembangkit listrik tenaga surya (PLTS), pengolahan sampah menjadi briket untuk masak serta bahayanya sampah plastic bagi lingkungan hidup, kemudian dilanjutkan dengan demo perangkat PLTS serta dipertunjukan briket hasil pengolahan sampah.

Adapun langkah-langkah yang dilakukan selama sosialisasi ini adalah sebagai berikut:

Langkah 1 : Peserta diberikan materi tentang jenis jenis pembangkit yang ramah lingkungan, seperti PLTS, PLTB, PLTA.

Langkah 2 : Peserta diberikan contoh komponen komponen PLTS serta cara kerja nya.

Langkah 3 : Peserta diberikan materi tentang pengolahan sampah sederhana yang menghasilkan briket.

Langkah 4 : Peserta diberikan materi tentang dampak penggunaan sampah plastic bagi lingkungan hidup, seperti pencemaran udara dan pencemaran air laut.

Langkah 5 : Setelah penyampaian materi, dilakukan diskusi dan tanya jawab tentang materi yang disampaikan.

Langkah 6 : Peserta diharapkan dapat melanjutkan dan menyebarluaskan informasi tentang energi baru terbarukan kepada kerabat, anggota keluarga dan tetangga sekitarnya.

\section{HASIL DAN PEMBAHASAN}

Kegiatan pengabdian masyarakat yang dilakukan oleh Tim P2M STT PLN pada hari Kamis, 22 November 2018 di SMP Annida Al Islamy Kel. Duri Kosambi, Cengkareng, mendapat sambutan dan antusias yang sangat besar. Pemahaman siswa-siswi tentang energi listrik masih belum diimbangi dengan pemahaman mengenai jenis jenis pembangkit listrik ysng ramah lingkungan serta dampaknya bagi lingkungan hidup.

Adapun susunan acara pada kegiatan sosialisasi dapat dilihat pada tabel di bawah ini : 
Tabel 2. Susunan Acara Pelaksanaan P2M

\begin{tabular}{|c|c|c|c|}
\hline No & Waktu & Acara & Penanggung Jawab \\
\hline 1 & $07: 30-08: 00$ & Registrasi Peserta & Erlina \\
\hline 2 & 08:00 - 08:15 & Pembukaan Acara & Jumiati \\
\hline 3 & $08: 15-08: 25$ & $\begin{array}{l}\text { Sambutan } \\
\text { - Kepala Sekolah } \\
\text { - Wali Kelas }\end{array}$ & $\begin{array}{l}\text { - Drs. M Haidar } \\
\text { - Ni'matun }\end{array}$ \\
\hline 4 & $08: 25-08.35$ & Sambutan Ketua Tim P2M & Retno Aita Diantari \\
\hline 5 & $08: 35-08: 55$ & Jenis Jenis Pembangkit Energi Listrik & Tasdik Darmana \\
\hline 6 & $08: 55-09: 15$ & $\begin{array}{l}\text { Pengenalan Pembangkit Listrik Tenaga } \\
\text { Surya (PLTS) }\end{array}$ & Retno Aita Diantari \\
\hline 7 & $09: 15-09: 35$ & $\begin{array}{llll}\begin{array}{l}\text { Pengolahan } \\
\text { Alternatif }\end{array} & \text { Sampah } & \text { Sebagai } & \text { Energi } \\
\end{array}$ & Syarif Hidayat \\
\hline 8 & $09: 35-09: 55$ & $\begin{array}{l}\text { Dampak Kerusakan Lingkungan bagi } \\
\text { Lingkungan Hidup }\end{array}$ & I Made Indradjaja MB \\
\hline 9 & $09: 55-10: 30$ & Diskusi \& Tanya Jawab & Jumiati \\
\hline 10 & $10: 30-11: 00$ & Pembacaan Doa \& Penutup & Jumiati \\
\hline
\end{tabular}

Kegiatan sosialisasi ini berjalan dengan lancar dan dihadiri sekitar 40 peserta yang terdiri dari seluruh siswa-siswi SMP Annida Al Islamy Kelas 9. Besarnya minat para siswa terhadap kegiatan ini menunjukan betapa pentingnya informasi tentang pemanfaatan sumber daya alam yang dapat menghasilkan energi, serta dampak yang ditimbulkan jika alam ini rusak, terhadap kehidupan mahluk di dunia.

Hasil kegiatan P2M secara garis besarnya dapat dilihat berdasarkan beberapa komponen berikut ini:

a. Keberhasilan target jumlah peserta yang mencapai $100 \%$. Hal ini terlihat dari daftar hadir sebanyak 40 orang (hampir memenuhi kelas) bahkan permintaan guru-guru dan para siswa untuk dilakukan juga dikelas yang lain. Hal ini didukung oleh Yayasan Shiraathu Al-Rahim Duri Kosambi, khususnya Bidang Pendidikan yang menaungi Sekolah Annida Al Islamy, serta Kepala Sekolah dan seluruh jajarannya.

b. Ketercapaian tujuan sosialisasi mencapai $90 \%$. Hal ini terlihat dari adanya peningkatan pengetahuan siswa dari yang kurang memahami tentang jenis-jenis pembangkit energi listrik, energi listrik terbarukan serta dampaknya bagi lingkungan hidup sampai bagaimana upaya dalam menjaga kelestarian lingkungan.

c. Adanya diskusi yang aktif dari para siswa, berupa pertanyaan pertanyaan tentang pembangkit energi listrik, serta pertanyaan tentang menjaga kebersihan di lingkungan sekolah.

d. Ketercapaian target materi yang disampaikan mencapai $80 \%$. Hal ini terlihat dari cara mengisi kuesioner yang diberikan oleh Tim P2M mengenai isi materi dari para nara sumber.

e. Secara keseluruhan kegiatan P2M berupa sosialisasi energi baru terbarukan untuk pelajar SMP Annida Al Islamy di Kelurahan Duri Kosambi, Kecamatan Cengkareng dinilai berhasil, karena manfaatnya langsung dirasakan oleh para siswa, guru dan sekolah tersebut. 
Terang : Jurnal Pengabdian Pada Masyarakat Menerangi Negeri

e-ISSN: 2655-5948

Vol. 1, No. 2, Juli 2019

p-ISSN: 2655-5956

DOI: https://doi.org/10.33322/terang.v1i2.313

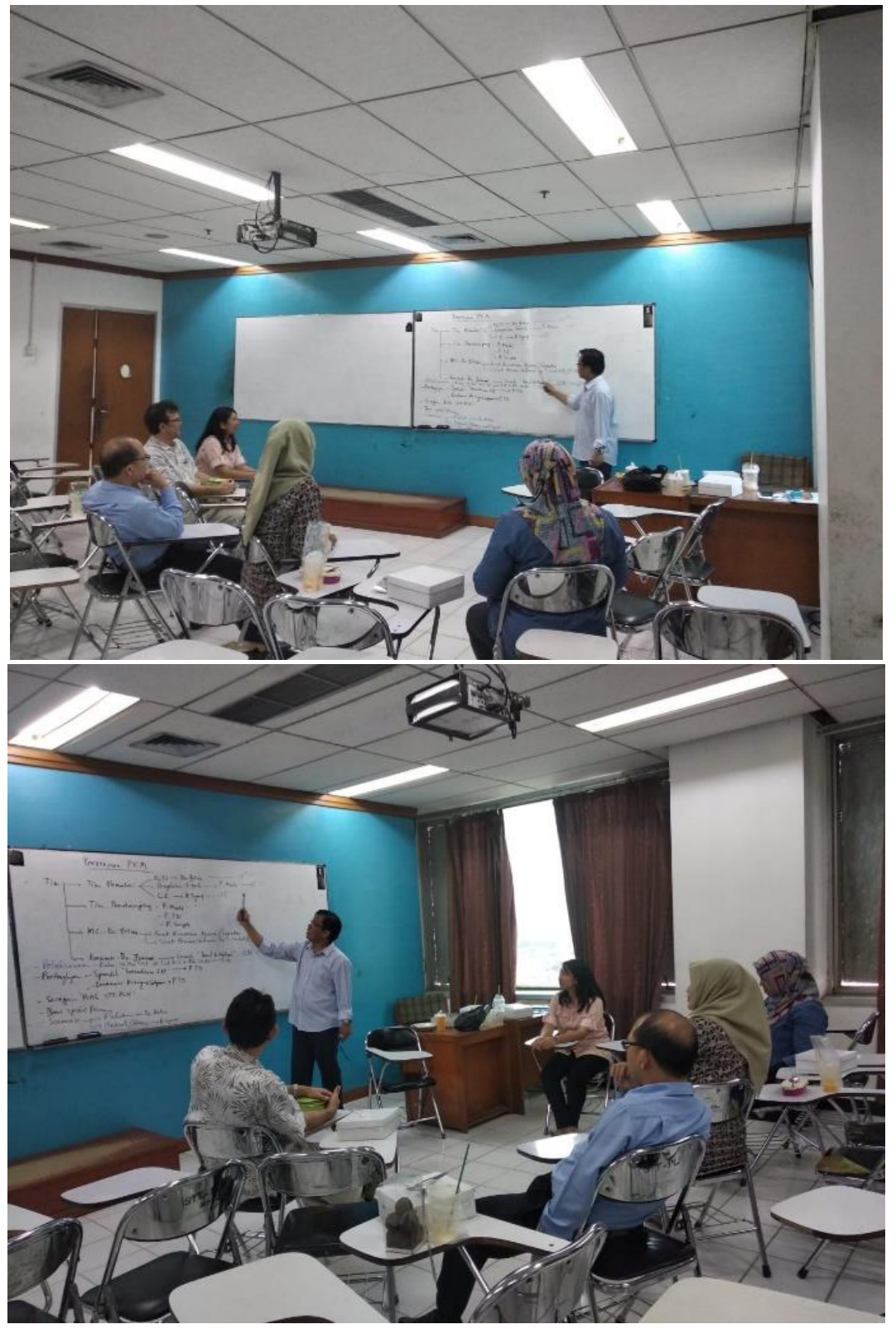

Gambar 2. Rapat persiapan dalam rangka merancang format pelaksanaan P2M
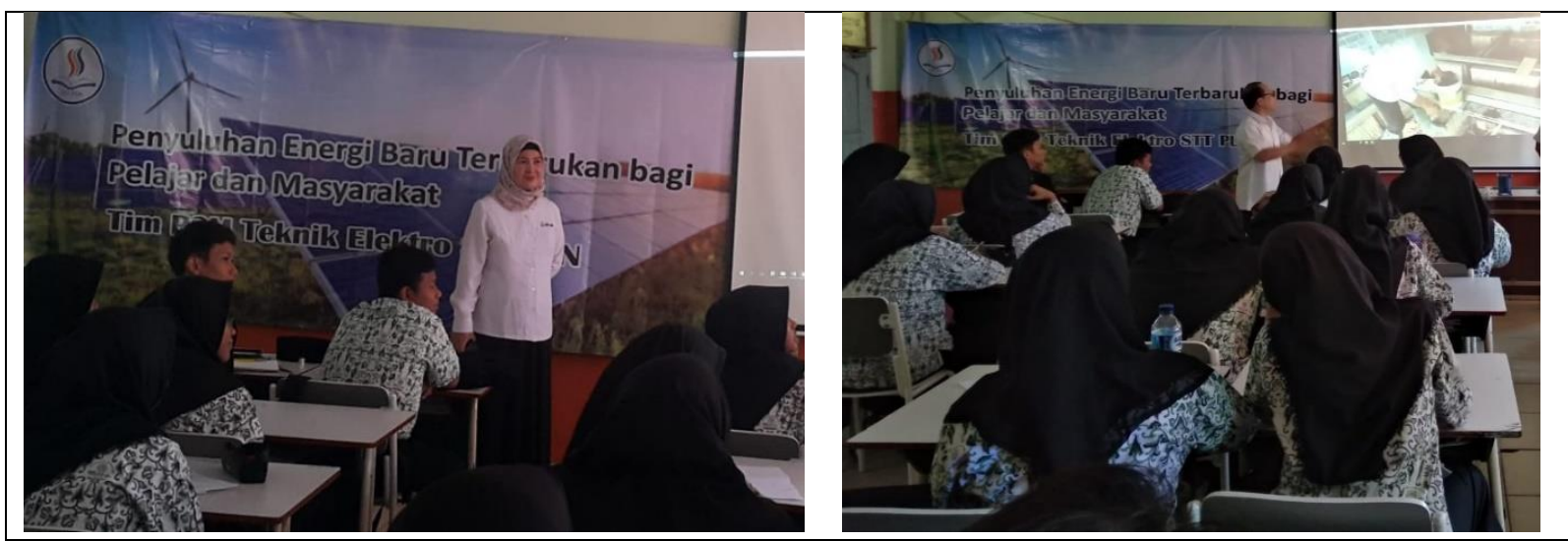
Terang : Jurnal Pengabdian Pada Masyarakat Menerangi Negeri

e-ISSN: $2655-5948$

Vol. 1, No. 2, Juli 2019

p-ISSN: 2655-5956

DOI: https://doi.org/10.33322/terang.v1i2.313

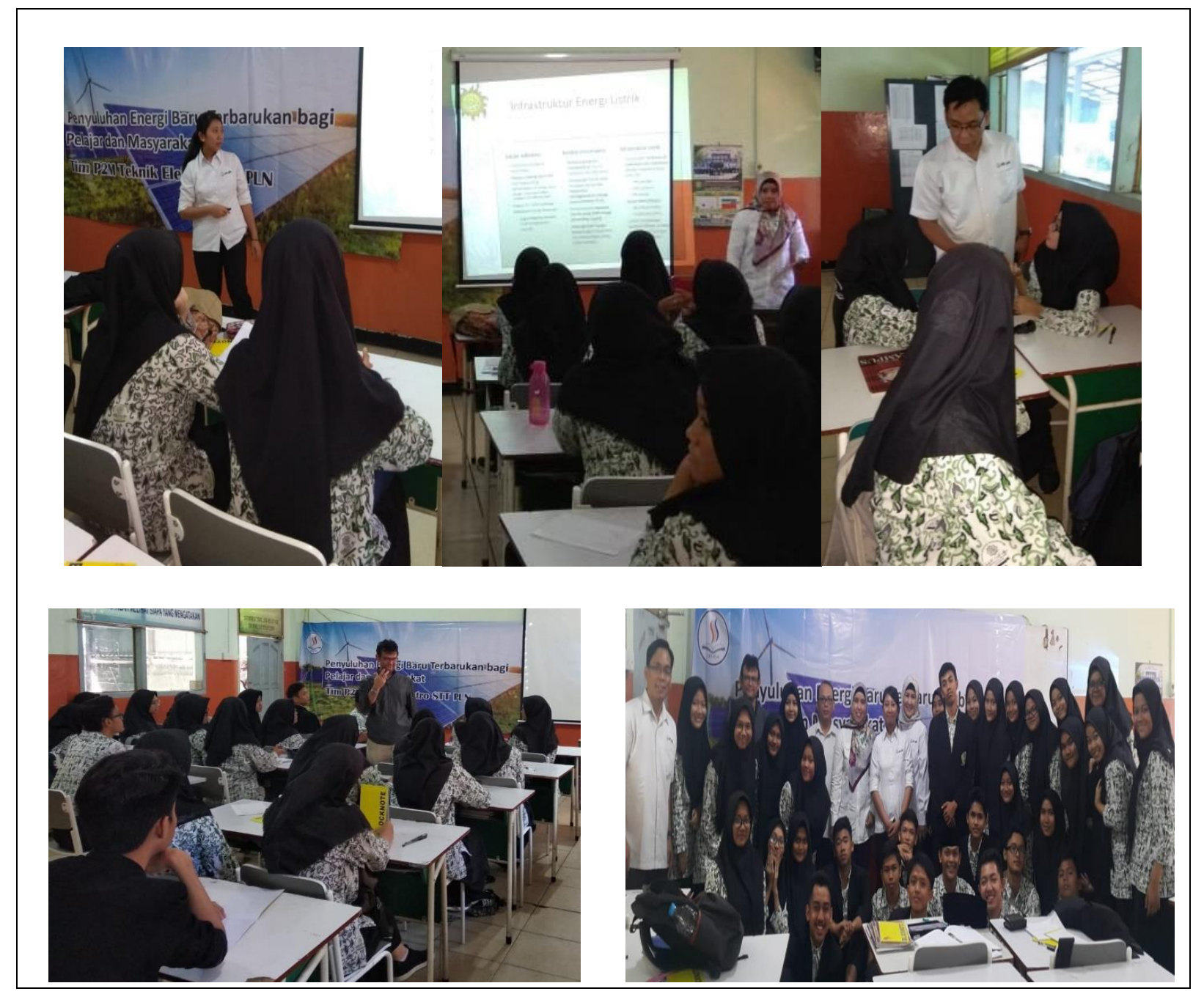

Gambar 3. Pelaksanaan Sosialisasi Energi Baru Terbarukan

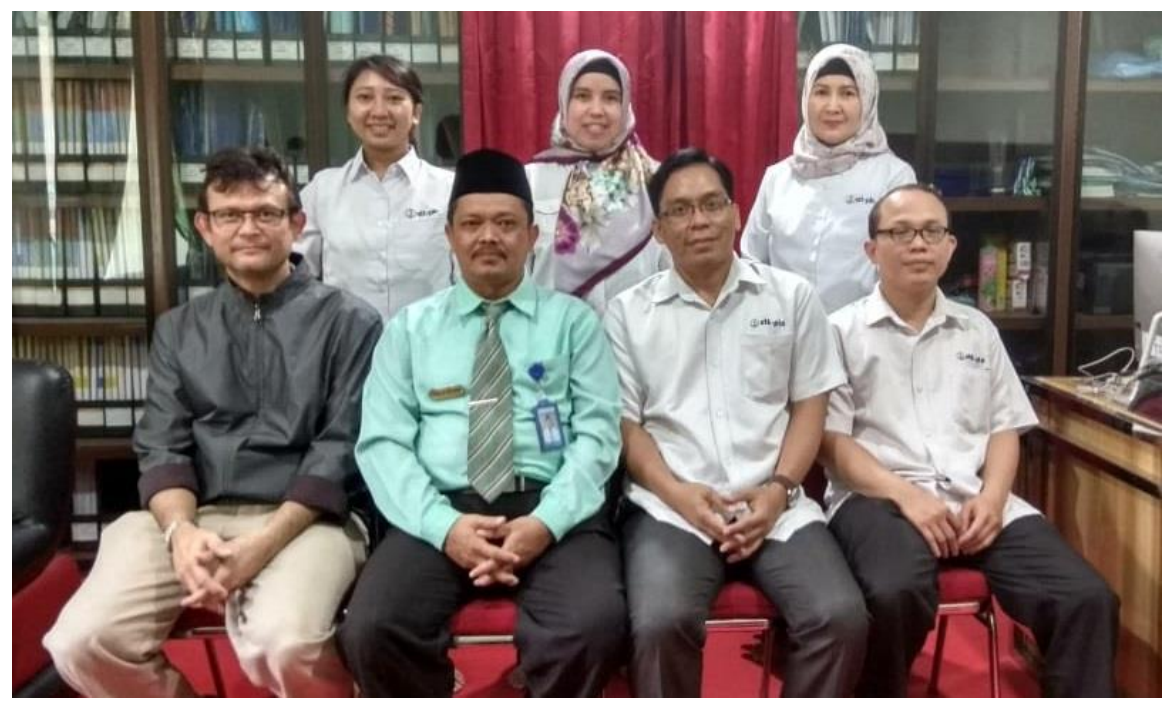

Gambar 4. Rapat Evaluasi Kegiatan P2M 


\section{KESIMPULAN}

Kurangnya pemahaman siswa mengenai proses terjadinya energi listrik membuat mereka belum banyak melakukan penghematan energi listrik dalam kehidupan sehari-hari. Selama ini, sebagaian besar siswa dalam menggunakan energi listrik tidak memikirkan dampaknya terhadap kelestarian lingkungan hidup. Dengan adanya sosialisasi yang telah dilakukan oleh Tim P2M, hal ini membangkitkan kesadaran mereka bagaimana proses terjadinya listrik serta bagaimana menghasilkan listrik dari sumber daya alam yang ramah lingkungan.

\section{SARAN}

Sosialisasi yang dilakukan oleh Tim P2M STT PLN dapat memberi dampak positif dan ini merupakan langkah kecil namun memberi nilai yang sangat besar. Untuk itu apa yang sudah dilakukan dalam kegiatan Pengabdian Masyarakat ini dapat dilanjutkan pada semester depan dengan lokasi yang berbeda.

\section{UCAPAN TERIMA KASIH}

Penulis mengucapkan terima kasih kepada Ketua STT-PLN, KLPPM STT-PLN, Pengurus Yayasan Shiraathu Al-Rahim Duri Kosambi, khususnya Bidang Pendidikan yang menaungi Sekolah Annida Al Islamy, Kepala Sekolah, Guru-Guru dan seluruh jajarannya, serta seluruh adik adik di Sekolah Annida Al Islamy Ketua STT-PLN, dan kepada Kepala Departemen Elektro yang telah memberi dukungan yang membantu pelaksanaan kegiatan pengabdian pada masyarakat dan penulisan artikel ini.

\section{DAFTAR PUSTAKA}

[1] ESDM, "Mengarusutamakan EBT Sebagai Energi Masa Depan," Jurnal Energi, Media Komunikasi Kementrian Energi dan Sumber Daya Mineral, pp. 9-11, 2016.

[2] Anonim, "Roadmap Pembangunan Energi Baru Terbarukan Untuk Ketahanan Energi," Dana Mitra Lingkungan, 2015.

[3] I. Kholiq, "Pemanfaatan Energi Alternatif Sebagai Energi Terbarukan Untuk Mendukung Substitusi BBM," IPTEK, pp. 75-91, 2015. 